\title{
EFFECTIVE CORPORATE GOVERNANCE MECHANISMS, OWNERSHIP STRUCTURE AND FINANCIAL REPORTING QUALITY: EVIDENCE FROM OMAN
}

\author{
Muneer Rajab Amrah ${ }^{1}$ and Mohammed Mahdi Obaid ${ }^{2}$ \\ ${ }^{1}$ Assistant Professor of Accounting, Faculty of Administrative Sciences, Seiyun \\ University, Hadramout, Yemen. \\ Email: amrh2015@yahoo.com \\ ${ }^{2} \mathrm{PhD}$ Student, Tunku Puteri Intan Safinaz, School of Accountancy, \\ Universiti Utara Malaysia, Kedah, Malaysia. \\ Email: mohammedmahdiuum@gmail.com
}

\begin{abstract}
This study aimed to examine the relationship between corporate governance effectiveness and financial reporting quality among family and non-family owned companies in the Sultanate of Oman. This study used a panel dataset for 68 companies listed on the Muscat Securities Market for 6 years from 2013 to 2018. The study contributes to the literature by extending previous financial reporting quality with a consideration of the Sultanate of Oman business environment where family ownership control is more common. Additionally, this study contributes by using a composite measure of corporate governance mechanisms to capture the combined effect of corporate governance effectiveness on the propensity of financial reporting quality, based on the agency's theoretical framework. This study is based on the difference between family and non-family owned firms with Type I and Type II agency problems, with differences in ownership and control. This study contributes to the literature by examining the influences of corporate governance effectiveness on financial reporting quality, which is expected to be different between family and non-family firms. The empirical results indicate that the association between corporate governance effectiveness and its financial reporting quality is positive and significant for both, the full sample as well as the non-family firms. However, this relationship appears to be weaker for family owned firms.
\end{abstract}

Keywords: corporate governance effectiveness, financial reporting quality, family and non-family firms, Oman. 


\section{INTRODUCTION}

Family businesses are often an overlooked form of business ownership in both developed and developing countries, yet they constitute the majority of the businesses. The differences between these countries in managing family firms have been discussed by several studies; for example, La Porta, Silanes and Shleifer (1999) by using 27 countries from around the world found that family firms are the most common type of economic organization in these countries. In a study by Barontini and Caprio (2006) using 675 firms listed in 11 European countries found that the firms controlled by families account for 53 per cent of the sampled companies. Anderson and Reeb (2003) in a study of 403 companies among the S\&P 500 industries in the United States (US) determined that more than one-third of these companies are family firms. Claesens, Djankov and Lang (2000) of 2,980 listed companies in nine countries in East Asia, claimed that companies controlled by families account for 66 per cent of the companies studied. Besides, of 304 listed companies in four Arab countries, Omran, Bolbol and Fatheldin (2008) found that the firms controlled by families account for 68 per cent of the sampled companies.

Although many family-owned firms have a considerable presence in the publicly traded corporations, family-owned firms are different from non-family firms. According to the agency theory, family owners expend more effort to monitor managers than other types of large shareholders. This suggests that, compared to non-family companies, the Type I agency problem (manager-owner) may be less prevalent in family firms due to a less information asymmetry existing among manager-owners (Anderson, Mansi \& Reeb, 2004). However, the Type II agency problem is perceived to be more severe in family firms because family owners may have both the incentive and the ability to extract private benefits at the expense of minority shareholders, which is harmful to firm value (Cheung, Rau \& Stouraitis, 2006).

Also, ownership and control in family firms are not separated. In other words, family-owned firms have both a larger share of equity and executives in their companies. In non-family firms, ownership is dispersed among small shareholders and the monitoring role is concentrated among professional managers. Consequently, these differences have led to different styles of management, levels of motivation among the founders, family values and decision-making processes (Daily \& Dollinger, 1992; Chua, Chrisman 
\& Chang, 2003). Therefore, based on the differences between family and non-family owned firms with Type I and Type II agency problems, and the difference in ownership and control; the influence of corporate governance effectiveness on financial reporting quality is expected to be different for family and non-family firms.

Corporate governance is one of the main elements that determines the condition of a firm's system and its ability to survive economic shocks. Consequently, good corporate governance contributes to sustainable economic development by enhancing the performance of companies and increasing their access to outside capital (Sarbah \& Xiao, 2015). Although various management issues in family firms have been analysed, there are still aspects left for research. Important issues that remain include the relationship between family control and corporate governance structures and the influence of generation on these governance mechanisms (Duller, 2012). Further, having high-quality corporate governance increases the company's value because it can signal a good indicator to investors and shareholders regarding the quality of its financial reporting and overall internal control system. This attention to corporate governance quality can be explained by the fact that there are financial and nonfinancial costs attached to corporate governance quality, such as the reputation of its auditor and director, the director's success, stock price and company values.

Recent studies have used the aggregate measurement for corporate governance quality in investigating the impact of corporate governance performance and the quality of its financial reporting. Most of these studies provide interesting evidence viewing that aggregate measurement of corporate governance quality has many desirable effects, such as high performance, high financial reporting quality and high audit quality. For example, Brown and Caylor (2006), Gompers, Ishii and Metrick (2003) and Larcker, Richardson and Tuna (2007) stated a positive relationship between the quality of corporate governance and the firm's performance. Besides, DeFond, Hann and Xuesong (2005) reported that aggregate measure of corporate governance quality positively affects market reaction, accounting conservatism (Lara, Osma \& Penalva, 2007; Krishnan \& Visvanathan 2008) and earnings quality (Kent, Routledge \& Stewart, 2010; Baber, Liang \& Zhu, 2012). Similarly, Zaman, Hudaib and Haniffa (2011), Sharma, Sharma and Ananthanarayanan (2011) and Cassell, Giroux and Omer (2012) find a positive association between 
the quality of corporate governance, audit quality and disclose that weaker quality of corporate governance is more likely to have lower audit quality.

The current study contributes to the literature by extending the scope of previous work regarding financial reporting quality by considering the business environment in the Sultanate of Oman where family ownership and control are more common. Furthermore, the current study contributes by considering the effect of corporate governance mechanisms as an aggregate measure to capture the combined effect of these mechanisms on the propensity of the financial reporting quality based on a framework conceptualized according to the agency theory. Finally, based on the difference between family and non-family owned firms with Type I and Type II agency problems, and the differences in ownership and control, this study further contributes to the literature by examining the influence of corporate governance effectiveness on financial reporting quality, which is expected to be different between family and non-family firms.

\section{PREVIOUS LITERATURE}

\section{Corporate Governance for Family and Non-Family Firms}

The importance of good corporate governance to improve the competitiveness of the capital market sector and attract foreign investors into the local market has been increasingly recognised by the Omani government (Al-Busaidi, 2008), thus achieving better corporate performance and enhancing a better relationship with all stakeholders (Shankaraiah \& Rao, 2004). According to the corporate governance perspective, companies that adopt high-quality corporate governance practices are better-governed. Beekes and Brown (2006) argue that corporate governance quality affects the financial reporting disclosure and that increasing the quality of corporate governance is associated with more timely disclosure. Recent corporate governance literature posits that corporate governance quality is not reflected by a single mechanism of corporate governance because corporate governance mechanisms are interdependent or substitute each other (Larcker et al., 2007; Brown, Beekes \& Verhoeven, 2011; Baber et al., 2012). Therefore, considering a broader measure of corporate governance that includes internal and external mechanisms is more appropriate for measuring the quality of corporate governance. 
Consistent with this, prior literature established that corporate governance quality leads to accounting conservatism (Krishnan \& Visvanathan, 2008), enhances discretionary accruals quality (Kent et al., 2010) and increases audit quality (Sharma et al., 2011; Cassell et al., 2012). In addition, higher corporate governance quality in companies enhances the quality of their financial reporting, transparency and disclosure of accounting information (Ashbaugh-Skaife, Collins \& LaFond, 2006; Sengupta, 1998; Aldamen \& Duncan, 2012). Therefore, the role of the board of directors and audit committee, as the main internal mechanism of corporate governance, is important to provide key monitoring of these agency costs.

Lefort and Urzua (2008) indicate that the board of directors is an essential internal governance mechanism that provides the main control over agency costs, and deals with the problems relating to the management of the organization. Specifically, board quality leads to the validity of accounting statements, which causes banks to have greater faith in internal governance mechanisms, thus reducing borrowing costs. In addition, companies with high board quality reduction in the default risk due to the reduced agency problems and improved monitoring of managerial actions, are likely to provide credible financial reports (Bhojraj \& Sengupta, 2003; Anderson et al., 2004; Piot, Missonier \& Piera, 2007; Ertugrul \& Hegde, 2008).

However, the role, structure, and composition of the board of directors differ between family firms and non-family firms. Generally, these structures are determined by the business size, complexity, and maturity of the owning family (IFC Corporate Governance). In the early years of their existence, the majority of family businesses created a board of directors to comply with legal requirements. These were known as "paper boards" whose purpose was primarily limited to approving the financial business, dividends and other procedures that the law required via the board of directors (Kosnick, 1987).

Some studies have found that family firms have a slightly smaller board of directors and fewer independent directors than non-family firms (Chen \& Cheng, 2008). In family firms, it is a norm to see the same people serving as the manager and on the board of directors, as well as becoming owners of the company. Such a governance structure adds little value to the family business, which can lead to conflict and inefficiency in the company, particularly regarding the oversight of strategic decisions (IFC Corporate Governance). 
Prior research on financial reporting quality has empirically linked with board characteristics in an individual investigation. For instance, Rahman and Ali (2006) showed that the role of independent directors in increasing the quality of earning management is insignificant. Kent et al. (2010) reported that board independence does not constrain earrings management as proxies by discretionary accruals quality. Dhaliwal, Naiker and Navissi (2010) found that independent directors who do not sit on the audit committee are insignificantly associated with accruals quality. Nonetheless, board size is reported to influence company performance and financial reporting quality. Yermack (1996) examined the association between board size and company performance for large US publicly- traded companies and found that board size is negatively associated with Tobin's Q, a performance proxy. Beasley (1996) reported a positive relation between board size and the likelihood of financial statement fraud. Vafeas (1999) suggests that holding a higher number of board meetings is an alternative value-relevant attribute of the corporate board. Board meeting provides the directors with a vein to discuss and approve decisions relating to strategic and monitoring duties. There is considerable research linking board meetings with company performance and financial reporting quality. For example, Vafeas (1999) reported that initially board meetings are negatively related to performance, but after years of increased board meetings, the company's performance improves, which suggests that more meetings enhance company's performance. Zaman et al. (2011) reported that holding more meetings is associated with high audit quality.

Carcello, Hermanson and Riley (2002) claimed that more expert directors on the board, in terms of having a higher number of directorships, demand high-quality auditors because they have more loss in fraud or opportunistic cases and hiring such auditors may be associated with less opportunistic cases. Fama and Jensen (1983) argue that directors with multiple board appointments can signal director expertise in control decisions. Schnake and Williams (2008) revealed that directors with multiple directorships are more likely associated with misconduct and this association is moderated by board size. More recent literature also provided inconsistent results with regard to whether multiple directorships enhances or destroy the quality of financial reporting (Dhaliwal et al., 2010; Sharma \& Kuang 2014). 
The audit committee is an important element of corporate governance and is concerned with establishing and monitoring the accounting processes to provide relevant and credible information to the firm's stakeholders (Pincus, Rusbarsky \& Wong, 1989; Beasley, 1996). Anderson et al. (2004) argue that the quality of audit committees is to ensure the soundness and quality of internal accounting and control practices. However, the effectiveness of the audit committee can be jeopardized by the presence of too many family members (Bettinelli, 2010). The agency theory predicts that family firms will have less demand for an effective audit committee because controlling families want to take advantage of minority shareholders. Focusing on a sample of 523 Hong Kong firms for the period of 1999-2000, Jaggi and Leung (2007) found that audit committees play a significant role in constraining earnings management even when ownership is concentrated in the hands of fewer people. However, they also found that the effectiveness of audit committees is significantly reduced when family members are present on corporate boards, particularly when family members dominate these boards. In addition, Wong (2011), based on 385 Hong Kong listed firms, confirms that family firms are associated with less audit committee independence and financial expertise.

Some studies have examined the effect of audit committee characterises on financial reporting quality; for example, Raghunandan, Read and Rama (2001) showed that audit committee independence was associated with a stronger internal audit function. Klein (2002) revealed a negative association between audit committee independence and abnormal accruals. Consistent with the later result, Bédard, Chtourou and Courteau (2004) indicated that audit committee independence constrains aggressive earning management. Recent evidence also holds the proposition of effective role provided by independent directors on the audit committee over the quality of financial reporting (Ahmad-Zaluki \& Wan-Hussin 2010; Dhaliwal et al. 2010; Krishnan, Yuan \& Wanli, 2011). There have been studies looking at the role and importance of audit committee size on a variety of outcomes. For example, Lin, Li and Yang (2006) contended and reported that the audit committee size is significantly associated with high-quality earnings. Persons (2009) found that companies with large audit committees have earlier voluntary disclosure and is less likely to commit fraudulent financial reporting. Ghosh, Marra and Moon (2010) found audit committee size positively associated with earning management. 
It has been posited that an active audit committee is expected to provide effective monitoring, and thus the reliability of financial reporting is enhanced (DeZoort, Hermanson, Archambeault \& Reed, 2002). Several studies have been conducted to examine the impact of audit committee meetings on financial reporting output and audit process. The findings of this literature suggest that more audit committee meetings is associated with fewer financial reporting problems and with higher audit quality (DeZoort et al. 2002). For example, McMullen and Raghunandan (1996) found that companies with financial reporting problems held fewer audit committee meetings. Using earnings management proxies, Xie, Davidson and DaDalt (2003) and Saleh, Iskandar and Rahmat (2007) reported that there was a negative relationship between audit committee meetings and earnings management. However, Lin et al. (2006) and Krishnan and Visvanathan (2008) reported an insignificant association between audit committee meetings, accounting restatements occurrence and accounting conservatism respectively. The audit committee is mainly responsible to oversee the financial reporting process, auditing and internal control processes; therefore, having financial experts constitute an imperative condition to ensure that the audit committee effectively performs its tasks. Xie et al. (2003) and Saleh et al. (2007) reported that companies with financial experts on audit committees were less likely to practice earning management. There is a considerable number of research conducted and have reported that only accounting expertise audit committee associated with accounting conservatism (Krishnan \& Visvanathan, 2008), internal control quality (Zhang et al., 2007; Goh, 2009), less occurrence of assets misappropriation (Mustafa \& Youssef, 2010), and high quality earnings (Dhaliwal et al., 2010; Krishnan et al., 2011).

Prior literature argues on the importance of an external auditor in adding credibility to financial reporting and in reducing the agency problem (Jensen \& Meckling, 1976; Watts \& Zimmerman, 1978). However, these responsibilities need high-quality auditors to be effectively discharged (DeAngelo, 1981). Audit firms are usually grouped based on size, whether a firm is one of the recognized top tier audit firms (Kent et al., 2010). Big audit firms, Big-4, are recognized as the top tier audit firms and they can provide a higher quality audits than smaller audit firms (Francis, 2004). Lawrence et al. (2011) posit that the size of Big-4 audit firms assists them to supply high audit quality because this size can support more standardized 
audit methodologies, robust training programs, and more choices for suitable second partner reviews. Further, Kent et al. (2010) note that Big-4 audit firms have more financial accounting expertise and knowledgeable accounting standards staff that assist them to detect and predict irregular accounting practices. There are large numbers of empirical researches emerging to examine the audit quality of Big-N audit firms. The evidence largely confirms a higher audit quality of Big-N audit firms (Francis, 2004). For instance Francis and Wilson (1988) found that Big-N audit firms are chosen by companies with high agency costs because management and shareholders believe the ability of such auditors to reduce agency costs. Francis and Krishnan (1999) show that Big-N auditors have lower thresholds for issuing modified audit reports, which indicates greater reporting conservatism. Francis (2004) reviewed audit quality literature and reported that Big-N audit firms are associated with the high-quality audit report and financial statements.

The relevant literature reviewed above shows contrasting findings of the individual characteristics of the board of directors, audit committee and audit quality with financial reporting quality. This approach has been criticized in recent literature for its inability to represent the quality of the board of directors or the audit committee. Larcker et al. (2007) argue that mixed evidence of corporate governance effect on company performance or financial reporting quality can be attributed to using individual mechanisms. Further, Brown et al. (2011) note that using a single corporate governance mechanism is not appropriate to measure overall corporate governance quality and that research should use a composite corporate governance measure to provide a better measurement for corporate governance quality. Subsequently, it is reported that the relevancy of individual machines in the corporate governance system is tailored to other mechanisms (Baber et al., 2012). Past studies by O'Sullivan, Percy and Stewart (2008), Hoitash, Hoitash and Bedard (2009), Goh (2009), Ishak and Al-Ebel (2011), Fallatah and Dickins (2012), Lary and Taylor (2012), Aldamen and Duncan (2012), and Ramly (2013) combined a number of characteristics as a proxy for governance factors to produce a combined score for corporate governance. Applying the same reasoning, this study examined the board of directors, audit committee and external audit characteristics (independence, size, frequency meetings, expertise, directorship and audit reputation), as a composite measure for corporate governance effectiveness, to capture their 
combined effect on determining whether or not they are associated with the financial reporting quality for companies listed on the Muscat Securities Market.

In addition, the contrasting findings above ignore the influence of the institutional structure of companies and countries, such as the ownership structure. According to Desender (2009), the effectiveness of the board of directors and audit committee depends on the institutional structure of companies and countries, such as ownership structure. For example, Bhojraj and Sengupta (2003), and Kosnick (1987) show that companies with concentrated family ownership could not obtain the optimum quality reports even with an effective board of directors, because the board of directors is appointed to comply with legal requirements only. Several studies have shown a difference in firm performance between family and non-family firms (e.g. Anderson \& Reeb, 2003; Villalonga \& Amit, 2006; Miller, Breton-Miller \& Lester, 2007; Chahine, 2007; Ibrahim \& Abdul Samad, 2011; Ong \& Gan, 2013). However, the empirical results for the performance between family and non-family owned firms are mixed. For example, Anderson and Reeb (2003), Villalonga and Amit (2006) show that family firms perform better than non-family firms, while Miller et al. (2007) indicate that firms that are owned and controlled by families or employ relatives as managers never exhibit superior performance. A study by Chahine (2007) on the Gulf Cooperation Council (GCC) countries finds that private investor ownership business and personal relationships dominate the financial preferences, and, therefore, have a negative effect on bank value. Therefore, it is important to study family-owned firms because, compared to non-family owned firms, they are common among public firms in both developed and developing countries.

This study attempted to extend these prior studies by examining whether there is any difference in the association between corporate governance effectiveness and financial reporting quality between family and non-family owned companies in the Sultanate of Oman where familybased ownership control is widespread and the legal protection of minority shareholders is weak (Omran et al., 2008). Within this weak regulatory framework, the controlling family can expropriate minority shareholders by appointing closely related directors. This practice might reduce the effectiveness of corporate governance mechanisms that influence the quality 
of financial reporting. Based on the above arguments and previous studies, this study expects that the influence of corporate governance effectiveness on the quality of financial reporting is weaker in family firms than in nonfamily firms.

\section{METHODOLOGY}

\section{Data Sources and Sample Selection Criteria}

The population of this study consisted of financial and non-financial firms that were listed on the Muscat Securities Market from 2013 to 2018. The total number of companies listed on the Muscat Securities Market was 116 at the end of 2018. Due to the differences in the regulatory requirements, and the characteristics of their financial reports, which are different from those of non-financial firms, 31 banks and other financial institutions were excluded from the population (Lorca, Ballesta \& Meca, 2011; Byun, 2007; Kim, Simunic, Stein \& Yi, 2009). In addition, due to unavailable online financial reporting for some companies, 17 companies with missing data were excluded from the sample population. The final sample of this study for a single year is 68 firms. More specifically, this study used a balanced panel dataset, which has multiple observations of the same economic units. Each element has two subscripts, the group identifier, i (in this case 68 companies), and within the group index denoted by $t$, which identifies time (in this case 2013-2018). Based on the balance panel dataset approach, each year from 2013-2018 has a sample size of 68 firms. The total number of observations for the entire period was 408 (68 firms for 6 years).

\section{Empirical Model}

This study used a panel dataset, which has multiple observations on the same economic units. Each element has two subscripts, the group identifier, i (in this case 68 companies) and within the group index denoted by $t$, which identifies time (in this case 2013-2018). Based on the above sample this study started by reporting the descriptive statistics for the full sample of 408 firms, the family sample of 240 firms and the nonfamily sample of 168 firms. Subsequently, a descriptive analysis provided more descriptive information that enabled the data to be understood and interpreted more appropriately. Using the means from randomly drawn 
samples, the independent two-sample t-test was used to test whether the population means were significantly different between the family and nonfamily firms. Additionally, this study used the following regression for the financial reporting quality:

$$
F R Q_{i t}=a_{0}+\beta_{1} C G E F F_{i t}+\beta 2 F S_{i t}+\beta 3 L E V_{i t}+\beta 4 R O A i t+\varepsilon i t
$$

where: i represents company, $\mathrm{t}$ time period, FRQ is financial reporting quality, CGEFF is corporate governance effectiveness, FS is firm size, LEV is leverage, ROA is return on assets, and $\varepsilon$ is the error term.

\section{Panel Data Estimation}

The financial reporting quality model in the previous equation is first estimated by using ordinary least squares (OLS), which treats all the observations for all the periods as a single sample. The OLS model ignores the panel nature of data and assumes that zit has no serial correlation. However, panel data may have group effects, time effects, or even both. These effects are either fixed or random. A fixed-effects model assumes differences in intercepts across groups or periods, whereas a random-effects model explores differences in error variances. For a given observation, an intercept varying over units results in the structure:

$$
F R Q_{i t}=a_{0}+\beta_{1} C G E F F_{i t}+\beta_{2} F S_{i t}+\beta_{3} L E V_{i t}+\beta 4 R O A_{i t}+\left(u_{i}+\varepsilon i t\right)
$$

where: ui is the individual-level effect, and git is the disturbance term. The ui is either correlated or uncorrelated with predictor variables. The ui is always assumed to be uncorrelated with eit. If the ui is uncorrelated with the predictor variables, it is known as the random-effects model, but if the ui is correlated with the predictor variables, it is known as the fixed-effects model. The Hausman test is used to differentiate between the fixed effects model and the random-effects model. This test uses the difference between the two estimated covariance matrices (which is not guaranteed to be positively definite) to weigh the difference between the fixed effects model and the random-effects model vectors of slope coefficients. In contrast, the Breusch-Pagan (LM) test (Breusch \& Pagan, 1980) uses the OLS model as the null hypothesis, and the random-effects model as the alternative. 


\section{Measurement of the Variables}

The dependent variable of this study was financial reporting quality; this study used accruals quality as a proxy for financial reporting quality. The measure employs a Dechow and Dichev's (2002) accrual quality model by Francis, LaFond, Olsson and Schipper (2005), which has recently been considered as a better proxy for financial reporting quality (Aboody, Hughes \& Liu, 2005; Biddle, Hilary \& Verdi, 2009; Spiceland, Yang \& Zhang, 2015; Yoo, Lim, \& Chang, 2013). This measure is based on the observation that accruals map into cash flow realizations and regardless of managerial intent, the accrual quality is affected by the measurement error in accruals. In Dechow and Dichev's (2002) approach, the estimated residuals from firm-specific regressions of working capital accruals on past, present, and future cash flow from operations capture total accruals estimation error by management and are viewed as an inverse measure of earnings quality. Francis et al. (2005) extended the Dechow and Dichev (2002) original accrual quality model by adding two additional variables, i.e. change in revenue and property, plant and equipment (PPE) for more complete characterization of the relation between accruals and cash flow. The following equation of accruals quality adopted as a proxy of financial reporting quality:

$\Delta \mathrm{TCA}_{\mathrm{it}} / \operatorname{Assets}_{\mathrm{it}}=\beta_{0}+\beta_{1} \mathrm{CFO}_{\mathrm{it}-1} / \operatorname{Assets}_{\mathrm{it}}+\beta_{2} \mathrm{CFO}_{\mathrm{it}} / \mathrm{Assets}_{\mathrm{it}}+\beta_{3} \mathrm{CFO}_{\mathrm{it}}$ ${ }_{+1} /$ Assets $_{\mathrm{it}}+\beta_{4} \Delta \mathrm{REV}_{\mathrm{it}} /$ Assets $_{\mathrm{it}}+\beta_{5} \mathrm{PPE}_{\mathrm{it}} /$ Assets $_{\mathrm{it}}+\varepsilon_{\mathrm{it}}$

Where:

$\Delta \mathrm{TCA}_{\mathrm{it}}=$ Firms i total current accruals in year $\mathrm{t}=\left(\Delta \mathrm{CA}_{\mathrm{it}}-\Delta \mathrm{CL}_{\mathrm{it}}-\Delta \mathrm{Cash}_{\mathrm{it}}\right.$ $\left.+\Delta \mathrm{STD}_{\mathrm{it}}-\mathrm{Dep}_{\mathrm{it}}\right)$

$\Delta \mathrm{CA}_{\text {it }}=$ Change in current assets between year $\mathrm{t}-1$ and year $\mathrm{t}$

$\Delta \mathrm{CL}_{\mathrm{it}}=$ Change in current liabilities between year $\mathrm{t}-1$ and year $\mathrm{t}$

$\Delta$ Cash $_{\text {it }}=$ Change in cash and cash equivalents between year $\mathrm{t}-1$ and year $\mathrm{t}$

$\Delta \mathrm{STD}_{\mathrm{it}}=$ Change in debt included in current liabilities between year $\mathrm{t}-1$ and year $\mathrm{t}$

Dep $_{\mathrm{it}}=$ Depreciation and amortization expense.

Assets $_{\text {it }}=$ Firms i average total assets in year $\mathrm{t}$ and year $\mathrm{t}-1$

$\mathrm{CFO}_{\text {it }}=$ Firms i net cash flow form operation activities in year $\mathrm{t}$

$\triangle \mathrm{REV}_{\mathrm{it}}=$ Firm $\mathrm{i}$ Change in revenue for firm $\mathrm{i}$ from year $\mathrm{t}-1$ to year $\mathrm{t}$, and $\mathrm{PPE}_{\mathrm{it}}=$ Firm $\mathrm{i}$ Gross property, plant, and equipment for firm $\mathrm{i}$ in year $\mathrm{t}$. 
For each firm-year, the equation is estimated cross-sectionally for all firms (minimum 10 firms within each industry groups In the Sultanate of Oman, there are two industry groups - Industrial and Services.) using rolling 6-year windows. Accrual quality equal to the standard deviation of firm it estimated residuals. Larger standard deviations of residuals correspond to poorer accrual quality. Following DeFond et al. (2007) and Hashim and Devi (2008), the standard deviation score was multiplied by -1 so that a higher score indicates higher earnings quality, therefore higher financial reporting quality.

The definition of a family business is still subject to debate among researchers. For example, Anderson and Reeb (2003) define a family firm as either individuals or groups of founders or any close family relationship among the owners, directors or block holders. On the other hand, Maury (2006) describes family ownership as the degree of family presence on the board in addition to acknowledge the exerting dimensions of family power. Furthermore, Astrachan, Klein and Smyrnios (2002) define a family firm as consisting of three main dimensions - power, experience and culture of a family. However, Adams, Almeida and Ferreira (2009), and McConaughy, Walker, Henderson and Mishra (1998) explain family-owned firms based on family control and voting rights. From the above definitions, this study defined family firms in the Sultanate of Oman as private institutions that take the name of a family as well as individuals that have the same family name or any close form of family relationship among the owners. Accordingly, family ownership in this study was measured as a percentage of shares owned by family shareholders who own $5 \%$ The $5 \%$ cut-off was used because the majority of the listed companies in the Sultanate of Oman only disclose the ownership of the major shareholders who own $5 \%$ or above of the firm's total equity or more of a firm in respect of the total number of shares issued (Chahine, 2007; Al-Musalli \& Ismail, 2012). Therefore, to separate between family and non-family firms, this study used a dummy variable by assigning a value of one (1) for family firms if the major family shareholders own a stake of $5 \%$ or more of firm shares, and zero (0) otherwise for non-family firms.

This study developed its measure of corporate governance effectiveness for the following reasons. First, existing corporate governance quality measures are not globally accepted or applicable, and they do not imply 
the optimal corporate governance quality measures (Khanchel, 2007). Second, Brown et al. (2011) indicate that a clear or an agreed theory to guide researchers in verifying elements of corporate governance quality measures is non-existent and researchers arbitrarily constructed their measures. Third, there is a strand of high-quality research which uses their measures of corporate governance quality (e.g., Cassell et al., 2012; DeFond et al., 2005; Larcker et al., 2007; Sharma et al., 2011) and these researches provide evidence that more effective corporate governance enhances company value and financial reporting quality.

This study used nine characteristics of corporate governance to construct the measure of corporate governance effectiveness. Four board characteristics, four audit committee characteristics and one audit quality characteristic made up the composite measure of corporate governance effectiveness in this study. Following prior literature, corporate governance quality measure was built by the sum all these 9 characteristics of each company. However, these characteristics in most studies were either measured by continuous approach or by dichotomous approach. Therefore, to maintain the unity of the score, continuous variables were dichotomized based on a variable median or specific cut-off point. Based on this strategy, the highest score was 9 and the lowest, zero.

Four characteristics of the board were used to measure effectiveness. 1) board size, which is measured as the total number of directors available on the board (Anderson et al., 2004); a large size board can help the company to reduce the state of dependence and uncertainty exterior, and provide a broader set of knowledge and managerial experience (Pfeffer \& Salancik, 2003). 2) Independent directors measured as a proportion of the independent directors to total directors on the board (Lorca et al., 2011). Byrd and Hickman (1992) point out that an independent director contributes expertise and objectivity, which minimizes managerial entrenchment and expropriation of firm resources. 3) Board of director meetings, which is measured as the number of meetings held by the board during the year (Rahman \& Ali, 2006). Garcia and Ballesta (2009) considered that the number of board meetings to be a good proxy for the directors' monitoring effort. 4) Directorships measured as the total seats held by directors divided by the total number of directors (Ahmed \& Duellman, 2007). Lipton and Lorsch (1992) argue that multiple directorships can adversely affect the 
ability of the directors to monitor the management as they are distracted by the affairs of other organizations.

Four characteristics of the audit committee were used to measure effectiveness. 1) Audit committee size, which is measured as the number of directors on the audit committee (Goh, 2009). An audit committee of sufficient size can help the committee discharge its duties without overloading (Dezoort et al., 2002). 2) Independent directors on the committee, which is measured as the proportion of independent directors on the audit committee (Krishnan \& Visvanathan, 2008). Fama and Jensen (1983) state that the outside directors of an audit committee have an incentive to develop a reputation as experts in decision control, and, therefore, their existence on the board will enhance the internal control mechanism. 3) Audit committee meetings, which is measured as the number of meetings held by the audit committee per year (Raghunandan \& Rama, 2007). Menon and Williams (1994) consider frequent audit committee meetings as a signal for audit committee diligence. 4) Financial expertise for audit committee members, which is measured as the proportion of audit committee members with qualifications or experience in accounting or finances (Krishnan \& Visvanathan, 2008). DeZoort et al. (2002) argue that the knowledge of audit committee members in functional areas, such as auditing, accounting and finance, is regarded as a critical characteristic of audit committee effectiveness.

With regard to audit quality characteristic to measure corporate governance, quality is audit firm size, Audit firm size is proxies by prior studies as Big-N and non-Big-N audit firms (e.g. DeAngelo, 1981; Balsam et al., 2003; Kent et al., 2010; Schmidt \& Wilkins, 2013). This literature considers Big- 8,5 or 4 audit firms as high-quality audit providers because they have more skilled partners and staff and they have a strong reputation that motivates them to maintain high-quality audits. Fan and Wong (2005) consider Big-4 audit firms as the only effective external corporate governance mechanism in developing markets. However, the literature nowadays consider Deloitte \& Touche, Ernst and Young, PricewaterhouseCooper and KPMG as big audit firms around the world. Therefore, this study usedthe dichotomy variable to measure audit firm size where a company is assigned 1 if it is audited by one of the Big-4 audit firms and zero otherwise. Audit firm size is used previously to build corporate governance quality measures (e.g. Khanchel, 2007; O’Sullivan et al., 2008). 
This study included control variables that have been shown to have a significant impact on financial reporting quality. This study included firm size as one of the main control variables measured by the natural logarithm of total assets (Ghosh, 2005). Leverage was calculated as the percentage of total debt to total assets for the differences in the financial structure of firms and is used as a proxy for default risk (Fields, Fraser \& Subrahmanyam, 2010). This study included return on assets by dividing the net profit to total assets as an indicator of a firm's financial performance (Haniffa \& Huduib, 2006).

Table 1: Operational Measurement of Variables

\begin{tabular}{|c|c|c|}
\hline Variables & Acronym & Measurement \\
\hline $\begin{array}{l}\text { Financial } \\
\text { Reporting Quality }\end{array}$ & $\mathrm{FRQ}$ & $\begin{array}{l}\text { Absolute value of standard deviation of firm } \\
\text { residuals, from years } t-6 \text { to } t \text { from annual } \\
\text { cross-sectional estimations of the Francis et al. } \\
\text { (2005) model, multiplied by }-1\end{array}$ \\
\hline $\begin{array}{l}\text { Corporate } \\
\text { Governance } \\
\text { Effectiveness }\end{array}$ & CGEFF & $\begin{array}{l}\text { Score ranging between } 0 \text { and } 9 \text {, with higher } \\
\text { score indicates more effective corporate } \\
\text { governance and zero }(0) \text { otherwise. }\end{array}$ \\
\hline Family Control & FC & $\begin{array}{l}\text { Value of one (1) if the major family shareholders } \\
\text { own a stake of } 5 \% \text { or above of firm shares and } \\
\text { zero (0) otherwise. }\end{array}$ \\
\hline Firm Size & FS & The natural logarithm of total assets. \\
\hline Leverage & LEV & The percentage of total debt to total assets. \\
\hline Firm Performance & ROA & Net profit divided by total assets. \\
\hline
\end{tabular}




\section{RESULTS AND DISCUSSION}

\section{Descriptive Statistics}

Table 2: Descriptive Statistics for Full Sample, Family, And Non-Family Firms

\begin{tabular}{|c|c|c|c|c|c|c|}
\hline \multirow[t]{2}{*}{ Variables } & \multicolumn{4}{|c|}{$\begin{array}{c}\text { Full Sample } \\
\text { (Firms }=68) \\
(\mathrm{N}=408)\end{array}$} & \multirow{2}{*}{$\begin{array}{c}\begin{array}{c}\text { Family } \\
(\text { Firms }=40) \\
(\mathrm{N}=240)\end{array} \\
\text { Mean }\end{array}$} & \multirow{2}{*}{$\begin{array}{c}\begin{array}{c}\text { Non-Family } \\
(\text { Firms }=28) \\
(\mathrm{N}=168)\end{array} \\
\text { Mean }\end{array}$} \\
\hline & Mean & Std D & Min & Max & & \\
\hline $\mathrm{FRQ}$ & -0.639 & 0.631 & -3.837 & -0.011 & -0.6780 & -0.5840 \\
\hline CGEFF & 3.901 & 1.645 & 0.000 & 9.000 & 3.7125 & 4.1726 \\
\hline FS & 7.152 & 0.607 & 5.439 & 8.851 & 7.0108 & 7.3560 \\
\hline LEV & 0.540 & 0.248 & 0.053 & 1.082 & 0.5604 & 0.5109 \\
\hline ROA & 0.045 & 0.088 & -0.288 & 0.298 & 0.0285 & 0.0691 \\
\hline
\end{tabular}

$\mathrm{FRQ}$ (Financial reporting quality) $=$ Absolute value of standard deviation of firm residuals, from years $\mathrm{t}-6$ to $\mathrm{t}$ from annual cross-sectional estimations of the Francis et al. (2005) model, multiplied by -1 .

CGE (corporate governance effectiveness) $=$ Score ranging between 0 and 9 , with higher score indicates more effective corporate governance, and zero (0) otherwise.

FS (Firm Size $)=$ Natural logarithm of total assets.

LEV $($ Leverage $)=$ Percentage of total debt to total assets.

ROA (Return on Assets) $=$ Percentage of the net profit to total assets.

Table 2 presents the descriptive statistics for the full and separate sample of the family and non-family firms in the Sultanate of Oman. The descriptive statistics show a mean value of the financial reporting quality for the full sample of -0.639 with a minimum of -3.837 and a maximum of -0.011 , while the mean value of the financial reporting quality for family and non-family are -0.6780 and -0.5840 , respectively. The results show that the financial reporting quality is statistically and significantly different between family and non-family firms. This indicates that the quality of financial reporting in family firms is lower compared to non-family firms. The descriptive statistics also show that the average value of corporate governance effectiveness for the full sample is 3.901 with a minimum of zero and a maximum of nine, while the mean value for the effectiveness of the corporate governance for family firms is 3.7125 and 4.1726 for non-family firms. Additionally, the mean value of the firm size for the full sample is 7.152 with a minimum of 5.439 and a maximum of 8.851 , while the mean values for family and non-family firms are 7.0108 and 7.3560 , respectively. This indicates that the firm size (measured as total assets) in family firms is smaller than in non-family firms. Moreover, the average value of leverage 
(the proportion of total debt to total assets) for the full sample is 0.540 with a minimum of 0.053 and a maximum of 1.082 , while the leverage ratios for family and non-family are 0.5604 and 0.5109 , respectively. The results show that the family firms use more debt than non-family firms. However, the descriptive statistics for firm performance (measured as return on assets) for the full sample 0.045 with a minimum of -0.288 and a maximum of 0.298 , while the mean values for the family and non-family sample are 0.0285 and 0.0691 , respectively.

\section{Correlation Matrix}

Table 3: Pearson Correlation Matrix

\begin{tabular}{llccccc}
\hline & Variables & $\mathbf{1}$ & $\mathbf{2}$ & $\mathbf{3}$ & $\mathbf{4}$ & $\mathbf{5}$ \\
\hline 1 & FRQ & 1.0000 & & & & \\
2 & CGEFF & 0.1798 & 1.0000 & & & \\
3 & FS & 0.0907 & 0.2794 & 1.0000 & & \\
4 & LEV & -0.0599 & -0.1790 & -0.2344 & 1.0000 & \\
5 & ROA & 0.1686 & 0.2321 & 0.3489 & -0.4590 & 1.0000 \\
\hline
\end{tabular}

** and ${ }^{*}$ indicates significant at $1 \%$, and $5 \%$, respectively (2-tailed).

Refer to Table 2 for description of variables details.

A Pearson product-moment correlation ( $\mathrm{r}$ ) was computed to examine the correlation between the explanatory variables. As shown in Table 3, the correlations between explanatory variables are between 0.350 and -0.4590 . According to Hair et al. (2010), explanatory variables above \pm 0.7 indicate the existence of multicollinearity, which is a serious problem in regression. The correlation matrix shows that the correlation among explanatory variables is relatively low (below \pm 0.7 ) indicating that multicollinearity is not a problem. In addition, this study considered other diagnostic tests, such as normality and outliers, the results of the skewness and kurtosis for normality, as well as the univariate method for outliers, all of which confirms that there is no problem in respect of normality and outliers in this study. However, with respect to the problems of heteroscedasticity and autocorrelation, this study performed both tests for which the results confirm the presence of heteroscedasticity and autocorrelation. Hence, the standard errors in the financial reporting quality model are estimated based on Rogers (1993) clustered at the firm level. Clustering at the firm level produces an estimator that is robust to cross-sectional heteroscedasticity 
and within-panel correlation. This technique ensures that valid statistical inference on the coefficient is made.

\section{Regression Results}

Table 4: Random Effects Model for Full Sample, Family, and Non-Family Firms

\begin{tabular}{|c|c|c|c|c|c|c|}
\hline \multirow[t]{2}{*}{ Variables } & \multicolumn{2}{|c|}{$\begin{array}{l}\text { Full Sample } \\
\text { (Firms }=68 \text { ) }\end{array}$} & \multicolumn{2}{|c|}{$\begin{array}{c}\text { Family } \\
(\text { Firms }=40)\end{array}$} & \multicolumn{2}{|c|}{$\begin{array}{l}\text { Non-family } \\
\text { (Firms= 28) }\end{array}$} \\
\hline & Coeff. & t-Stat. & Coeff. & t-Stat. & Coeff. & t-Stat. \\
\hline CGEFF & 0.0603 & $2.81^{* \star *}$ & 0.0596 & $1.88^{*}$ & 0.0649 & $2.26^{* *}$ \\
\hline FS & -0.0009 & -0.01 & 0.0235 & 0.26 & -0.0453 & -0.48 \\
\hline LEV & 0.0946 & 0.61 & 0.0304 & 0.15 & 0.1968 & 0.81 \\
\hline ROA & 1.0980 & $2.51^{* *}$ & 1.2164 & $2.17^{* *}$ & 0.6909 & 0.94 \\
\hline Constant & -0.9691 & $-2.12^{* *}$ & -1.1160 & $-1.72^{*}$ & -0.6693 & -0.98 \\
\hline Hausman test & \multicolumn{2}{|c|}{9.12} & & & & \\
\hline Breusch-Pagan test & \multicolumn{2}{|c|}{$115.34^{* *}$} & & & & \\
\hline $\mathrm{R}^{2}$ & \multicolumn{2}{|c|}{0.123} & \multicolumn{2}{|c|}{0.156} & \multicolumn{2}{|c|}{0.120} \\
\hline $\mathrm{N}$ & \multicolumn{2}{|c|}{408} & \multicolumn{2}{|c|}{240} & \multicolumn{2}{|c|}{168} \\
\hline
\end{tabular}

${ }_{\star \star * *},{ }^{* \star}$ and * indicates significant at $1 \%, 5 \%$, and $10 \%$ respectively. Refer to Table 2 for description of variables details.

As shown in Table 4, the result of the Hausman test is $>0.05$ (i.e. not significant), and for the Breusch-Pagan (LM) test, it is $<0.05$ (i.e. significant). These two tests indicate that the random effects model is much preferred. Based on the random effects model, the results reveal that the corporate governance effectiveness for the full sample is significant (at $\mathrm{p}$-value $<0.01$ ) in the predicted positive direction, as shown by the estimated coefficient. This indicates a strong association between governance effectiveness and the financial reporting quality. This result supports that companies with a high quality of corporate governance can achieve an extent of quality in its financial reporting, due to the reduced agency problems and improved monitoring of managerial actions, and, consequently, are likely to provide credible financial reports (Anderson et al., 2004; Ertugrul \& Hegde, 2008; Piot et al., 2007).

To support the results in the full sample regression, this study divided the full sample into two groups - family and non-family - to examine whether there is any difference in the influence of corporate governance effectiveness on the financial reporting quality among family and non-family 
owned companies in the Sultanate of Oman. The result indicates that there is a significant positive relationship between the effectiveness of the corporate governance and the quality of financial reporting for the family firms (at p-value $<0.1)$. This suggests that the relationship between the corporate governance effectiveness and the financial reporting quality becomes weak when the firms have family ownership. For non-family firms, however, the relationship between the effectiveness of the corporate governance effectiveness and the financial reporting quality is consistently positive and significant (at $\mathrm{p}$-value $<0.05$ ). This result supports prior research arguments that family businesses create the mechanisms of corporate governance to comply with legal requirements, whereas non-family firms creates provision to the primary mechanism to control agency cost, and deal with problems relating to the management of the organization and improve the quality of financial reporting (Kosnick, 1987). Furthermore, this study supports the argument of Jaggi, Leung and Gul (2009), who contend that the appointment of a board of directors for family firms is to seek expertise and advice concerning the strategic direction of the firm rather than to monitor and control managerial activities. It is plausible that the role of the board and the role of the family have a substitution effect on the financial reporting quality that warrants further investigation.

Among the control variables, the relationship between firm size and financial reporting quality based on the full, family and non-family samples is not significant. Similarly, the effect of leverage on the quality of financial reporting for the full sample and the separate samples of family and non-family is not statistically significant. However, although the effect of performance on the full sample and family firms' sample is positive and significant, there is no significant effect for the non-family samples.

\section{CONCLUSION}

The objective of this study was to determine whether there is any difference in the relationship between corporate governance effectiveness and financial reporting quality among the family and non-family owned companies in the Sultanate of Oman. This study extended the scope of previous studies concerning the quality of financial reporting by considering the business environment in the Sultanate of Oman, where the financial markets remain 
less developed and the regulations and corporate control are still weak. In addition, firms in the Sultanate of Oman have a more concentrated ownership structure in which family ownership control is more common. This study contributes to the literature by providing a comparison between family and non-family firms in respect of its effect on the corporate governance as a composite measure to capture the combined effect of the features on the propensity of the quality of financial reporting based on a framework conceptualized in accordance with the agency's theory.

The empirical results of this study, based on the panel data for companies listed on the Muscat Securities Market from 2013 to 2018, reveal that the impact of the effectiveness of the corporate governance on the quality of financial reporting is positive and significant for the full and non-family sample, while this relationship becomes weak for family firms. The results of this study are useful to all stakeholders, as it provides them with an important indicator regarding the kind of controlling shareholder and the internal mechanisms of corporate governance that will protect their interests. This study also benefits the regulators and policymakers in the Sultanate of Oman, such as the Muscat Securities Market, because this study highlights several issues that can assist them in analysing the impact of other corporate governance mechanisms on this relationship in the Sultanate of Oman. For instance, regulators and policymakers might use the findings regarding the quality of financial reporting in the relationship to governance practice, to identify the important roles played by internal mechanisms of corporate governance as one of the basic mechanisms of the corporate governance system in the Sultanate of Oman.

This study has some limitations. First, the quality of the results can be judged based on the quality of the sample data. Second, the sample of this study only focuses on non-financial companies listed on the Muscat Securities Market. Other non-listed companies and financial companies have been disregarded. Therefore, the validation of the conclusions might not hold strongly for financial companies and other companies outside these lists. Therefore, this study only focuses on the board and audit committee characteristics and audit reputation as the main characteristics of corporate governance and their association with the quality of corporate governance when they work as a substitute or complementary measurement. Following the limitations highlighted above, future research could examine the issue 
of the financial reporting quality in different contexts (different economic cycles, different stock exchanges or different cultures). In particular, the validity of this model can also be examined in the different contexts of the GCC countries, in different time periods, and with different sample sizes.

\section{REFERENCES}

Aboody, D., Hughes., J. \& Liu, J. (2005). Earnings quality, insider trading, and cost of capital. Journal of Accounting Research, 43, 651-673.

Adams, R., Almeida, H., \& Ferreira, D. (2009). Understanding the relationship between founder-CEOs and firm performance. Journal of Empirical Finance, 16(1), 136-150.

Ahmad-Zaluki, N. A., \& Wan-Hussin, W. N. (2010). Corporate governance and earnings forecasts accuracy. Asian Review of Accounting, 18(1), 50-67.

Ahmed, S., \& Duellman, S. (2007). Accounting conservatism and board of director's characteristics: An empirical analysis. Journal of Accounting and Economics, 46(2/3), 411-437.

Al-Busaidi, H. (2008). Oman's experience in issuing and implementation of the code of corporate governance. Working Paper.

Aldamen, H., \& Duncan, K. (2012). Does adopting good corporate governance impact the cost of intermediated and non-intermediated debt? Accounting \& Finance, 52(1), 49-76.

Ali, A., Chen, T-Y., \& Radhakrishnan, S. (2007). Corporate disclosures by family firms. Journal of Accounting and Economics, 44(1), 238-286.

Al-Musalli, M. \& Ismail, K. (2012). Corporate governance, bank specific characteristics, banking industry characteristics, and intellectual capital (IC) performance of banks in Arab Gulf Cooperation Council (GCC) countries. Asian Academy of Management Journal of Accounting and Finance, 8(1), 115-135. 
Anderson, R., Mansi, S., \& Reeb, D. (2003). Founding family ownership and the agency costs of debt. Journal of Financial Economics, 68(3), 263-285.

Anderson, R., Mansi, S., \& Reeb, D. (2003). Founding-family ownership and firm performance: Evidence from the S\&P 500. Journal of Finance, $58(3), 1301-27$.

Anderson, R., Mansi, S., \& Reeb, D. (2004). Board characteristics, accounting report integrity, and the cost of debt. Journal of Accounting and Economics, 37(4), 315-347.

Ashbaugh-Skaife, H., Collins, D. \& LaFond, R. (2006). The effects of corporate governance on firms' credit ratings. Journal of Accounting and Economics, 42(2), 203-243.

Astrachan, J., Klein, S., \& Smyrnios, K. (2002). The F9PEC scale of family influence: A proposal for solving the family business definition problem. Family Business Review, 15(1), 45-58.

Baber, W. R., Liang, L. \& Zhu, Z. (2012). Associations between internal and external corporate governance characteristics: Implications for investigating financial accounting restatements. Accounting Horizons, 26(2), 219-237.

Ballesta, J., \& Meca, E. (2011). Ownership structure and the cost of debt. European Accounting Review, 20(2), 389-416.

Barontini, R., \& Caprio, L. (2006). The effect of family control on firm value and performance: Evidence from Continental Europe. European Financial Management, 12(5), 689-723.

Bartholomeusz, S., \& Tanewski, G. (2006). The relation between family firms and corporate governance. Journal of Small Business Management, 44(2), 245-267.

Beasley, M. (1996). An empirical analysis of the relation between the board of directors and financial statement fraud. The Accounting Review, $71(4), 443-465$. 
Bédard, J., Chtourou, S. M., \& Courteau, L. (2004). The effect of audit committee expertise, independence, and activity on aggressive earnings management. Auditing: A Journal of Practice \& Theory, 23(2), 13-35.

Bhojraj, S., \& Sengupta, P. (2003). Effect of corporate governance on bond ratings and yields: The role of institutional investors and outside directors. Journal of Business, 76(4), 455-475.

Biddle, G. C., Hilary, G., \& Verdi, R. S. (2009). How does financial reporting quality relate to investment efficiency? Journal of Accounting and Economics, 48(2-3), 112-131.

Breusch, T., \& Pagan, A. (1980). The Lagrange multiplier test and its applications to model specification in econometrics. Review of Economic Studies, 47(1), 239-253.

Brown, L. D., \& Caylor, M. L. (2006). Corporate governance and firm valuation. Journal of Accounting and Public Policy, 25(4), 409-434.

Brown, P., Beekes., W. \& Verhoeven, P. (2011). Corporate governance, accounting and finance: A review. Accounting and Finance, 51(1), 96-172.

Byrd, J., \& Hickman, K. (1992). Do outside directors monitor managers? Evidence from tender offer bids. Journal of Financial Economics, 32(2), 195-222.

Byun, H. (2007). The cost of debt capital and corporate governance practices. Asia-Pacific Journal of Financial Studies, 36(5), 765-806.

Carcello, J. V., Hermanson, D. R., Neal, T. L., \& Riley Jr, R. A. (2002). Board characteristics and audit fee. Contemporary Accounting Research, 19(3), 365-384.

Cassell, C. A., Giroux, G. A., Myers, L. A., \& Omer, T. C. (2012). The effect of corporate governance on auditor-client realignments. Auditing: A Journal of Practice \& Theory, 31(2), 167-188. 
Chahine, S. (2007). Activity-based diversification, corporate governance, and the market valuation of commercial banks in the Gulf Commercial Council. Journal of Manage Governance, 11(1), 353-382.

Chen, S., Chen, X., \& Cheng, Q. (2008). Do family firms provide more or less voluntary disclosure? Journal of Accounting Research, 46(3), 499-536.

Cheung, Y., Rau, P. \& Stouraitis, A. (2006). Tunneling, Propping and Expropriation: Evidence from Connected Party Transaction in Hong Kong. Journal of Financial Economics, 82(1), 343-386.

Chua, J., Chrisman, J., \& Chang, E. (2003). Are family firms born or made? An exploratory investigation. Family Business Review, 17(1), 37-54.

Claesens, S., Djankov, S., \& Lang, L. (2000). The separation of ownership and control in East Asia corporations. Journal of Financial Economics, $58(4), 81-112$.

Corporate Governance Codes and Principles - Oman. (2002). Available at: http://www.ecgi.org/codes/code.php?code_id=352

Daily, C., \& Dollinger, M. (1992). An empirical examination of ownership structure in family and professionally managed firms. Family Business Review, 5(2), 117-136.

DeAngelo, L. E. (1981). Auditor size and audit quality. Journal of Accounting and Economics, 3(3), 183-199

Dechow, P., \& I. Dichev. (2002). The quality of accruals and earnings: The role of accrual estimation errors. The Accounting Review, 177(2), 35-59.

DeFond, M. L., Hann, R. N., \& Xuesong, H. U. (2005). Does the market value financial expertise on audit committees of boards of directors? Journal of Accounting Research, 43(2), 153-193.

Desender, K. (2009). The relationship between the ownership structure and board effectiveness. University of Illinois at Urbana-Champaign, College of Business Working Papers, 09-0105. 
DeZoort, F., Hermanson, D. Archambeault, D., \& Reed, S. (2002). Audit committee effectiveness: A synthesis of the empirical audit committee Literature. Journal of Accounting Literature, 21(2), 38-75.

Dhaliwal, D. A. N., Naiker, V. I. C., \& Navissi, F. (2010). The association between accruals quality and the characteristics of accounting experts and mix of expertise on audit committees. Contemporary Accounting Research, 27(3), 787-827.

Duller, C. (2012). Corporate governance of family firms in subsequent generations. International Business \& Economics Research Journal, $12(3), 345-354$.

Ertugrul, M., \& Hegde, S. (2008). Board compensation practices and agency costs of debt. Journal of Corporate Finance, 1(5), 512-531.

Fallatah, Y., \& Dickins, D. (2012). Corporate governance and firm performance and value in Saudi Arabia. African Journal of Business Management, 6(36), 10025-10034.

Fama, E., \& Jensen, M. (1983). Separation of ownership and control. Journal of Law and Economics, 26(2), 301-325.

Fields, L. P., Fraser, D. R., \& Subrahmanyam, A. (2010). Board quality and the cost of debt capital: The case of bank loans. Journal of Banking and Finance, 36(5), 1536-1547.

Francis, J. R. (2004). What do we know about audit quality? The British Accounting Review, 36(4), 345-368.

Francis, J. R., \& Wilson, E. R. (1988). Auditor changes: A joint test of theory relating to agency costs and auditor differentiation. Accounting Review, 63(4), 663-682.

Francis, J. R., \& Krishnan, J. (1999). Accounting accruals and auditor reporting conservatism. Contemporary Accounting Research, 16(1), 135-165. 
Francis, J., LaFond, R., Olsson, P., \& Schipper, K. (2005). The market pricing of accruals quality. Journal of Accounting and Economics, 39(1), 295-327.

Francis, J. R., Khurana, I. K., \& Pereira, R. (2005). Disclosure incentives and effects on cost of capital around the world. Accounting Review, 80(41), 125-1162.

Garcia, E., \& Ballesta, J. (2009). Corporate governance and earnings management: A meta-analysis. Corporate Governance: An International Review, 17(5), 594-610.

Ghosh, A., Marra, A., \& Moon, D. (2010). Corporate boards, audit committees, and earnings management: Pre- and post-SOX evidence. Journal of Business Finance \& Accounting, 37(9-10), 1145-1176.

Ghosh, C., \& Sirmans, C. (2005). On REIT CEO Compensation: Does board structure matter. The Journal of Real Estate Finance and Economics, 30(4), 397-428.

Goh, W. (2009). Audit Committees, boards of directors, and remediation of material weaknesses in internal control. Contemporary Accounting Research, 26(2), 549-579.

Gompers, P., Ishii, J., \& Metrick, A. (2003). Corporate governance and equity prices. Quarterly Journal of Economics, 118(1), 107-155.

Haniffa, R. \& Hudaib, M. (2006). Corporate governance structure and performance of Malaysian listed companies. Journal of Business Finance and Accounting, 33(7/8), 1034-1062.

Hashim, H., \& S. Devi. (2008). Corporate governance, ownership structure and earnings quality: Malaysian evidence. Research in Accounting and Emerging Economies, 8(2), 97-123.

Hoitash, U., Hoitash, R., \& Bedard, C. (2009). Corporate governance and internal control over financial report information: A comparison of regulatory regimes. The Accounting Review, 84(3), 839-867. 
Ibrahim, H., \& Abdul Samad, F. (2011). Corporate governance mechanisms and performance of public-listed family-ownership in Malaysia. International Journal of Economics and Finance, 3(1), 105-115.

International Finance Corporation (IFC) Corporate Governance. (2013). Introduction to board of directors in a family business. Available at: http://www.smetoolkit.org/smetoolkit/en/content/en/6749/Introductionto-Board-of-Directors-in-a-Family-Business.

Ishak, Z. \& Al-Ebel, A. (2013). Board of directors, information asymmetry, and intellectual capital disclosure among banks in Gulf Co-Operation Council. Jurnal Pengurusan, 37, 33-43.

Jaggi, B., \& Leung, S. (2007). Impact of family dominance on monitoring of earnings management by audit committees: Evidence from Hong Kong. Journal of International Accounting, Auditing and Taxation, 16(2), 27-50.

Jaggi, B., Leung, S., \& Gul, F. (2009). Family control, board independence and earnings management: evidence based on Hong Kong firms. Journal of Accounting and Public Policy, 28(2), 281-300.

Jensen, M., \& Meckling, W. (1976). Theory of the firm: Managerial behavior, agency costs and ownership structure. Journal of Financial Economics, 3(1), 305-360.

Kent, P. Routledge, J., \& Stewart, J. (2010). Innate and discretionary accruals quality and corporate governance. Accounting and Finance, 50(1), $171-195$.

Khanchel, I. (2007). Corporate governance: Measurement and determinant analysis. Managerial Auditing Journal, 22(8), 740-760.

Kim, B., Simunic, A., Stein, T., \& Yi, H. (2009). Voluntary audits and the cost of debt capital for privately held firms: Korean evidence. Contemporary Accounting Research, 28(2), 585-615. 
Klein, A. (2002). Audit committee, board of director characteristics, and earnings management. Journal of Accounting and Economics, 33(3), $375-400$.

Kosnik, D. (1987). Greenmail: A study of board performance in corporate governance. Administrative Science Quarterly, 32(2), 163-185.

Krishnan, J., Yuan, W., \& Wanli, Z. (2011). Legal expertise on corporate audit committees and financial reporting quality. Accounting Review, 86(6), 2099-2130.

Krishnan, V., \& Visvanathan, G. (2008). Does the SOX definition of an accounting expert matter? The association between audit committee directors' accounting expertise and accounting conservatism. Contemporary Accounting Research, 25(3), 827-857.

La Porta, R. Lopez-de-Silanes, F., \& Shleifer, A. (1999). Corporate ownership around the world. Journal of Finance, 54(2), 471-517.

Lara, J. M. G., Osma, G., \& Penalva, F. (2007). Board of directors' characteristics and conditional accounting conservatism: Spanish evidence. European Accounting Review, 16(4) 727-755.

Larcker, D. F., Richardson, S. A., \& Tuna, I. (2007). Corporate governance, accounting outcomes, and organizational performance. Accounting Review, 82(4), 963-1008.

Lary, A., \& Taylor, D. (2012). Governance characteristics and role effectiveness of audit committees. Managerial Auditing Journal, 27(4), 336-354.

Lefort, F., \& Urzua, F. (2008). Board independence, firm performance and ownership concentration: Evidence from Chile. Journal of Business Research, 61(6), 615-622.

Lin, J. W., Li, J. F., \& Yang, J. S. (2006). The effect of audit committee performance on earnings quality. Managerial Auditing Journal, 21(9), 921-933. 
Lipton, M., \& Lorsch, J. (1992). Modest proposal for improved corporate governance. Business Lawyer, 12(3), 48-59.

Lorca, C. Ballesta, P., \& Meca, E. (2011). Board effectiveness and cost of debt. Journal of Business Ethics, 100(4), 613-631.

Maury, B. (2006). Family ownership and firm performance: Empirical evidence from Western European corporations. Journal of Corporate Finance, 3(4), 321-341.

McConaughy, D. L., Walker, M. C., Henderson Jr, G. V., \& Mishra, C. S. (1998). Founding family controlled firms: Efficiency and value. Review of Financial Economics, 7(1), 1-19.

McMullen, D. A., \& Raghunandan, K. (1996). Enhancing audit committee effectiveness. Journal of Accountancy, 182(2), 79-81.

Menon, K., \& Williams, J. (1994). The use of audit committees for monitoring. Journal of Accounting and Public Policy, 13(2), 121-139.

Miller, D., Le Breton-Miller, I., Lester, R. H., \& Cannella Jr, A. A. (2007). Are family firms really superior performers. Journal of Corporate Finance, 13(3), 829-858.

Mustafa, S., \& Youssef, N. B. (2010). Audit committee financial expertise and misappropriation of assets. Managerial Auditing Journal, 25(3), 208-225.

O’Sullivan, M., Percy, M., \& Stewart, J. (2008). Australian evidence on corporate governance attributes and their association with forwardlooking information in the annual report. Journal of Management and Governance, 12(1), 5-35.

Omran, M., Bolbol, A., \& Fatheldin, A. (2008). Corporate governance and firm performance in Arab equity markets: Does ownership concentration matter? International Review of Law and Economics, 28(1), 32-45.

Ong, T., \& Gan, S. (2013). Do family-owned banks perform better? A study of Malaysian banking industry. Asian Social Science, 9(7), 124-135. 
Persons, O. S. (2009). Audit committee characteristics and earlier voluntary ethics disclosure among fraud and no-fraud firms. International Journal of Disclosure \& Governance, 6(4), 284-297.

Pfeffer, J., \& Salancik, G. (2003). The external control of organizations: $A$ resource dependence perspective. Stanford California: Stanford University Press.

Pincus, K. Rusbarsky, M., \& Wong, J. (1989). Voluntary formation of corporate audit committees among NASDAQ firms. Journal of Accounting and Public Policy, 8(3), 239-265.

Piot, C. Missonier, R., \& Piera, F. (2007). Corporate governance, audit quality and the cost of debt financing of French listed companies. Working Paper.

Raghunandan, K., \& Rama, V. (2007). Determinants of audit committee diligence. Accounting Horizons, 21(3), 265-279.

Raghunandan, K., Read, W. J., \& Rama, D. V. (2001). Audit committee composition, "gray directors," and interaction with internal auditing. Accounting Horizons, 15(2), 105-118.

Rahman, A., \& Ali, M. (2006). Board, audit committee, culture and earnings management: Malaysian evidence. Managerial Auditing Journal, 21(7), 783-804.

Ramly, Z. (2013). The effect of corporate governance and shareholder monitoring mechanisms on cost of debt. International Journal of Human and Social Sciences, 7(4), 494-504.

Rao, N. Al-Yahyaee, K., \& Syed, M. (2007). Capital structure and financial performance: Evidence from Oman. Indian Journal of Economics and Business, 3(3), 250-261.

Rogers, W. (1993). Regression standard errors in clustered samples. Stata Technical Bulletin 13 (pp. 19-23): Stata Corporation. 
Saleh, N. M., Iskandar, T. M., \& Rahmat, M. M. (2007). Audit committee characteristics and earnings management: Evidence from Malaysia. Asian Review of Accounting, 15(2), 147-163.

Sarbah, A., \& Xiao, W. (2015). Good corporate governance structures: A must for family businesses. Open Journal of Business and Management, $3(1), 1-17$.

Schnake, E., \& Williams, R. J. (2008). Multiple directorships and corporate misconduct: The moderating influences of board size and outside directors. Journal of Business Strategies, 25(1), 1-14.

Sengupta, P. (1998). Corporate disclosure quality and the cost of debt. The Accounting Review, 73(4), 459-474.

Shankaraiah, K., \& Rao, D. N. (2002). Corporate governance and accounting standards in Oman: An empirical study on practices. Available at SSRN 480522.

Sharma, V., \& Kuang, C. (2014). Voluntary audit committee characteristics, incentives, and aggressive earnings management: Evidence from New Zealand. International Journal of Auditing, 18(1), 76-89.

Sharma, V. D., Sharma, D. S., \& Ananthanarayanan, U. (2011). Client importance and earnings management: The moderating role of audit committees. Auditing: A Journal of Practice \& Theory, 30(3), 125-156.

Spiceland, C. P., Yang, L. L., \& Zhang, J. H. (2016). Accounting quality, debt covenant design, and the cost of debt. Review of Quantitative Finance and Accounting, 47(4), 1271-1302.

Vafeas, N. (1999). Board meeting frequency and firm performance. Journal of Financial Economics, 53(1), 113-142.

Villalonga, B. \& Amit, R. (2006). How do family ownership, control and management affect firm value? Journal of Financial Economics, 80(2), $385-417$. 
Xie, B., Davidson, W. N., \& DaDalt, P. J. (2003). Earnings management and corporate governance: The role of the board and the audit committee. Journal of Corporate Finance, 9(3), 295-316.

Yermack, D. (1996). Higher market valuation of companies with a small board of directors. Journal of Financial Economics, 40(2), 185-211.

Yoo, Y., Lim, J., \& Chang, J. (2013). Financial reporting quality and acquisition profitability: evidence from Korea. Journal of Applied Business Research, 29(6), 1737-1750.

Young, M. N., Peng, M. W., Ahlstrom, D., Bruton, G. D., \& Jiang, Y. (2008). Corporate governance in emerging economies: A review of the principal-principal perspective. Journal of management studies, 45(1), 196-220.

Zaman, M., Hudaib, M., \& R. Haniffa. (2011). Corporate governance quality, audit fees and non-audit services fees. Journal of Business Finance \& Accounting, 38(1-2), 165-197. 